\title{
A NEW SPECIES OF PSEUDOLAMBRUS (BRACHYURA, PARTHENOPIDAE) FROM NEW CALEDONIA
}

\author{
BY \\ S. H. TAN ${ }^{1}$ ) \\ Raffles Museum of Biodiversity Research, Department of Biological Science, National \\ University of Singapore, 6 Science Drive 2, Singapore 117546, Republic of Singapore
}

\begin{abstract}
A new species of parthenopid crab, Pseudolambrus guinotae n. sp., is described. The single male specimen, which was collected from New Caledonia, most closely resembles Pseudolambrus planus (Rathbun, 1911) but can be easily differentiated from the latter by possessing a much longer rostrum.

\section{RÉSUMÉ}

Une nouvelle espèce de crabe Parthenopidae, Pseudolambrus guinotae n. sp. est décrite. Le seul spécimen mâle, récolté en Nouvelle-Calédonie, ressemble beaucoup à Pseudolambrus planus (Rathbun, 1911) mais se différencie aisément de ce dernier par la possession d'un rostre beaucoup plus long.
\end{abstract}

\section{INTRODUCTION}

The taxonomic status of the parthenopid genus Pseudolambrus Paul'son, 1875 , has long been confusing. This is partly due to the general belief that sexual dimorphism accounts for much of the external morphological variation among species, and is infrequently reported by authors, possibly due to lack of comparative material (see Tan, 2004). Tan (2004) revised the Parthenopidae and in a subsequent paper restricted Pseudolambrus to almost all western IndoPacific Ocean species, while the remaining species were placed in two other

\footnotetext{
1) e-mail: dbstansh@nus.edu.sg 
genera, Ochtholambrus Tan \& Ng, 2007, and Velolambrus Tan \& Ng, 2007 (see Tan \& Ng, 2007: 99).

$\mathrm{Ng}$ et al. (2008) recognized 15 species, with one additional species, Pseudolambrus bato Tan, 2008, recently described. As part of the revision of the Parthenopidae by Tan (2004), several Pseudolambrus species were described in that work that were not formerly published. I take this occasion to dedicate one of these species to one of the most respected figures in modern carcinology, Danièle Guinot.

\section{MATERIAL AND METHODS}

The material used for this study mainly originated from the Muséum national d'Histoire naturelle, Paris (MNHN), and the U.S. National Museum of Natural History, Smithsonian Institution, Washington, D.C. (USNM). The terminology follows McLay \& Tan (2009). Measurements presented here, in millimetres $(\mathrm{mm})$, are those of the carapace width and length, respectively, and in that very order.

\section{TAXONOMIC ACCOUNT}

Family PARTHENOPODAE MacLeay, 1838

Pseudolambrus Paul'son, 1875

Pseudolambrus guinotae n. sp. (fig. 1)

Material examined. - Holotype, male, 9.9 by $9.5 \mathrm{~mm}$ (MNHN), New Caledonia, Grotte Merlet, 20-30 m, J.-L. Menou coll., 19-21 January 1993.

Comparative material. - Pseudolambrus planus (Rathbun, 1911), male holotype, 18.1 by $16.1 \mathrm{~mm}$ (USNM 41446), Seychelles, Amirante I., HMS "Sealark", stn E21, $30 \mathrm{fms}$ (55 m), 17 October 1905; 1 female, 8.1 by $7.4 \mathrm{~mm}$ (MNHN), CHALCAL 1, Chesterfield and Bellona Plateau, stn D19, $19^{\circ} 06.73^{\prime} \mathrm{S} 158^{\circ} 41.75^{\prime} \mathrm{E}, 60 \mathrm{~m}, 12-31$ July $1984 ; 1$ female, 16.0 by $13.9 \mathrm{~mm}$ (MNHN), CORAIL 2, Chesterfield lagoon, stn DW144, $19^{\circ} 27.73^{\prime} \mathrm{S} 158^{\circ} 23.28^{\prime} \mathrm{E}, 50 \mathrm{~m}, 30$ August 1988.

Description. - Carapace (fig. 1) broadly pentagonal, slightly wider than long, surface rugose with fine reticulated patterning; rostrum much longer than broad, ventral surface with 2 rows of 6 oval depressions each, tip truncated. Epistome with lattice-like patterning, without any sub-circular structures. Posterior, metabranchial margins not continuous, notch at junction of 2 margins. Cheliped merus outer margin dentate, distalmost tooth largest, 


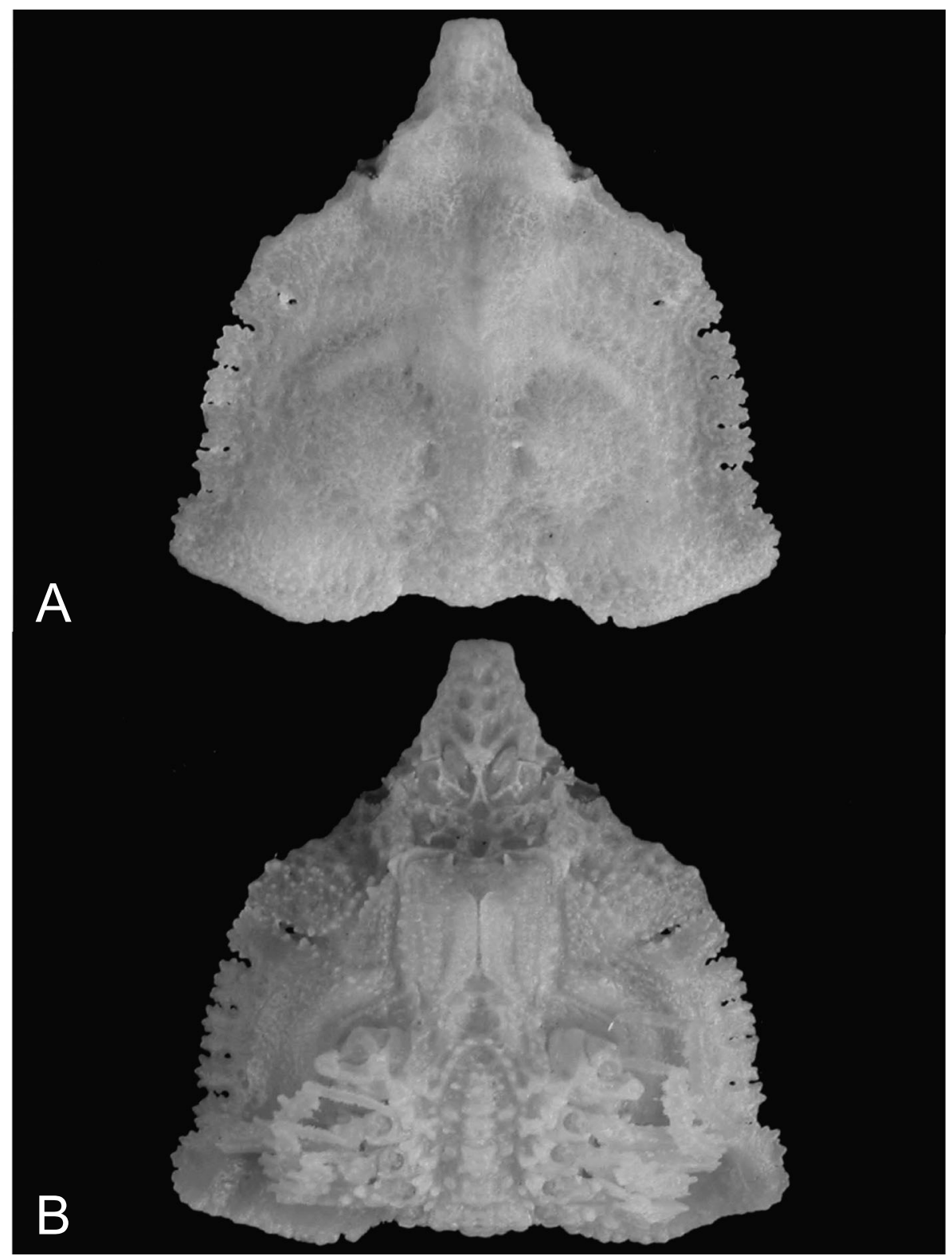

Fig. 1. Pseudolambrus guinotae n. sp.: A, B, holotype, male $9.9 \times 9.5 \mathrm{~mm}(\mathrm{MNHN})$, New Caledonia, Grotte Merlet, 20-30 m, J.-L. Menou coll., 19-21 January 1993. A, carapace, dorsal view; B, carapace, ventral view.

lamelliform, tooth tip rounded; teeth not fused with each other. Cheliped dactylus upper margin dentate, teeth prominent. 
Etymology. - I have great pleasure in naming this unique parthenopid species after the grande doyenne of carcinology, Danièle Guinot, a great friend and colleague whom I have the pleasure of working with.

Distribution. - Known only from the type locality, New Caledonia, from a depth between 20 and $30 \mathrm{~m}$.

Remarks. - The new species is so distinctive from all the other Pseudolambrus species that a diagnosis is sufficient to characterize it. Amongst all 15 Pseudolambrus species currently known (Ng et al., 2008), this species most closely resembles P. planus (Rathbun, 1911) in that the carapaces of both species are flattened dorso-ventrally. Pseudolambrus guinotae, however, is easily distinguished from $P$. planus in that it possesses a very long rostrum as well as two parallel rows of circular depressions on the ventral surface of the rostrum. In addition, the posterior margin is not continuous with the metabranchial margin in P. guinotae, but it is continuous in P. planus.

Tan (2004) diagnosed several other Pseudolambrus species similar to both $P$. planus and $P$. guinotae, but those will be described in a separate, comprehensive revision of the Parthenopidae.

\section{ACKNOWLEDGEMENTS}

I thank Peter Ng and Peter Castro for the opportunity to participate in this volume. I would also like to thank the staff, past and present, of the Muséum national d'Histoire naturelle for hosting me while studying this group of crabs for my dissertation. I thank three referees for their comments, which improved the quality of this paper. Part of this project is supported by the National University of Singapore grant ARF R-154-000-334-112.

\section{REFERENCES}

MACLEAY, W. S., 1838. On the brachyurous decapod Crustacea. Brought from the Cape by Dr. Smith. In: A. SMITH (ed.), Illustrations of the zoology of South Africa; consisting chiefly of figures and descriptions of the objects of natural history collected during an expedition into the interior of South Africa, in the years 1834, 1835, and 1836; fitted out by 'The Cape of Good Hope Association for Exploring Central Africa': together with a summary of African zoology, and an inquiry into the geographical ranges of species in that quarter of the globe, published under the Authority of the Lords Commissioners of Her Majesty's Treasury, Invertebratae, 4 [1849]: 53-71, pls. 2, 3. (Smith, Elder \& Co., London).

MCLAY, C. L. \& S. H. TAN, 2009. Revision of the crab genus Garthambrus Ng, 1996, with the description of two new genera and discussion of the status of Tutankhamen Rathbun, 1925 (Crustacea: Brachyura: Parthenopidae). Zootaxa, 2122: 1-50. 
NG, P. K. L., D. Guinot \& P. J. F. DAVIE, 2008. Systema Brachyurorum: Part I. An annotated checklist of extant brachyuran crabs of the world. Raffles Bulletin of Zoology, (Supplement) 17: 1-286.

PAUL'SON, O., 1875. Studies on Crustacea of the Red Sea with notes regarding other areas. Part 1. Podophthalmata and Edriophthalmata (Cumacea): 1-164, pls. 1-21. (Israel Programme for Scientific Translations, Jerusalem). [English translation of original Russian edition.]

Rathbun, M. J., 1911. No. XI. Marine Brachyura. In: The Percy Sladen Trust Expedition to the Indian Ocean in 1905, under the leadership of J. Stanley Gardiner, 3. Transactions of the Linnean Society of London, (Zoology) (2) 14: 191-261, figs. 1, 2, pls. 15-20.

TAN, S. H., 2004. A systematic revision of the Parthenopidae (Crustacea: Decapoda: Brachyura): 1-730. (Unpubl. Ph.D. Thesis, Department of Biological Sciences, National University of Singapore).

— - 2008. A new species of Pseudolambrus (Crustacea: Brachyura: Parthenopidae: Parthenopinae) from Panglao, Bohol, the Philippines. Zootaxa, 1731: 63-68.

TAN, S. H. \& P. K. L. NG, 2007. Descriptions of new genera from the subfamily Parthenopinae (Crustacea: Decapoda: Brachyura: Parthenopidae). Raffles Bulletin of Zoology, (Supplement) 16: 95-119.

First received 15 July 2009.

Final version accepted 29 July 2009. 